\title{
As imagens conversam
}

\section{Wilton Montenegro ${ }^{1}$}

Resumo: Este ensaio relaciona fotografia e memória, utilizando as leituras que os filósofos Jacques Derrida e Paul Ricouer, principalmente, fazem de um dos primeiros conceitos escritos por Freud, em 1895, bahnung, inédito por 30 anos, no qual estabelece uma analogia da formação da memória com a fotografia e com o funcionamento de uma câmera cinematográfica.

Palavras-chave: Imagem; memória; bahnung; fotografia.

\section{The images talk}

\begin{abstract}
This essay relates photography and memory, using the readings that philosophers Jacques Derrida and Paul Ricoeur, mainly, do about one of the first concepts written by Freud, in 1895, bahnung, unprecedented for 30 years, where he lays down an analogy between memory formation, photography and cinematographic camera operation.
\end{abstract}

Keywords: Image; memory; bahnung; photography.

1 Wilton Montenegro nasceu em Manaus, Amazonas, e mora no Rio de Janeiro desde 1960. Artista, fotógrafo e teórico, escreve sobre o ver e a imagem técnica. Publicou fotos em mais de um milhar de livros e catálogos de arte; em uma centena de capas de discos; em jornais e revistas no mundo todo; fez em parceria com os artistas, vários vídeos e filmes de arte; realizou dois curta metragens sobre os indígenas da Aldeia Maracanã, e faz um terceiro, relacionando-os com os Guajajaras do Maranhão. E-mail: wiltonmontenegro@gmail.com. ORCID: http://orcid.org/0000-0001-82735614. Rio de Janeiro, Brasil. 


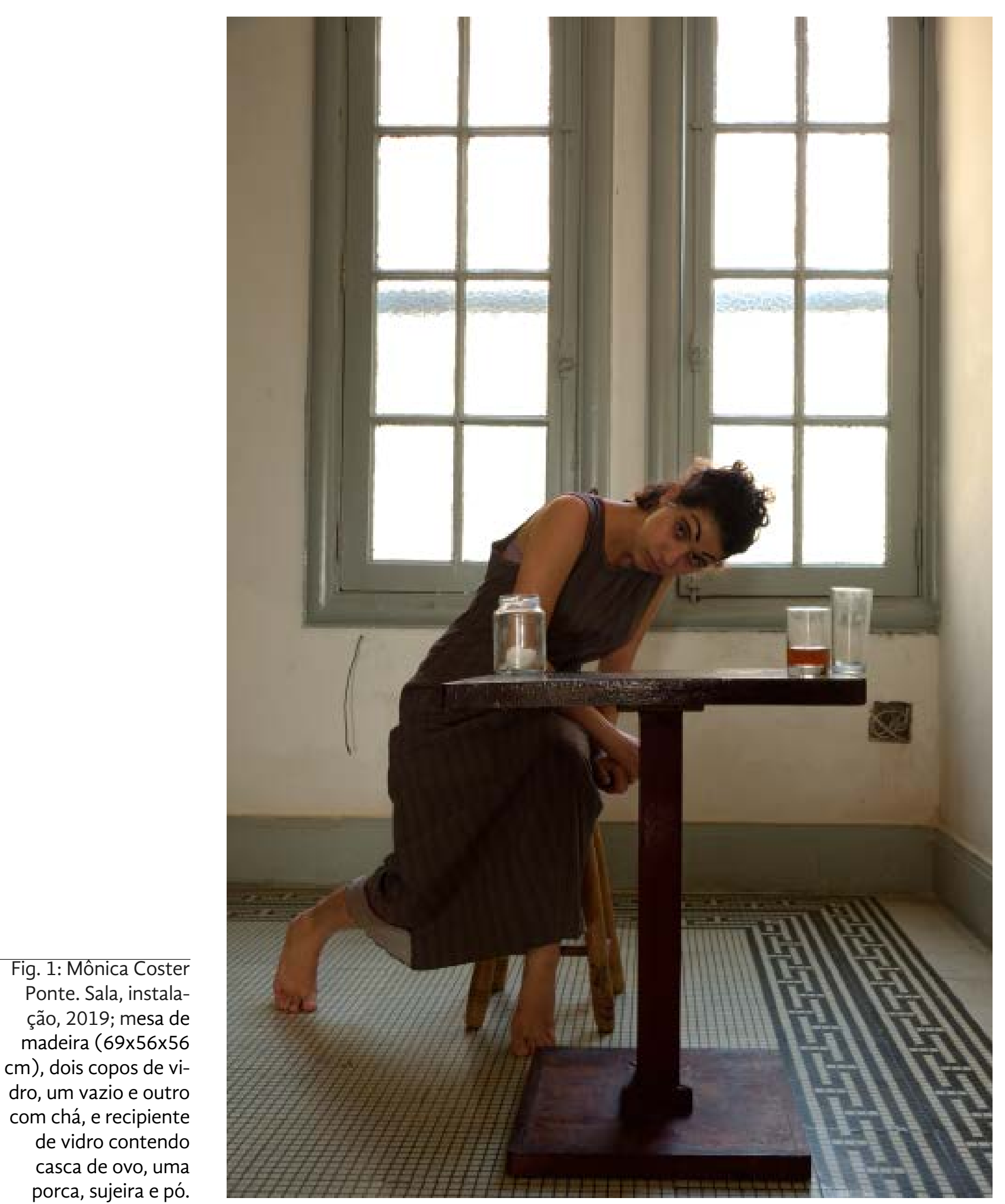

Aqui apresentada em fotografia com a presença da artista (foto Wilton Montenegro). Os três recipientes de vidro são movimentados pela extensão de uma mesa, através da telecinese de uma criança, até que um deles caia no chão. Sala é onde o vazio pode repousar na beira da mesa, em hesitação. (MCP). 
(...) mas sempre há algo que perfura a linguagem e sangra em nosso cérebro, que entende somente a linguagem, mas não entende de onde ela vem, isto é, de nervos, perfurações e ramificações de estímulos corpóreos, como gostava de pronunciar em suas palestras, segundo Krauss, o Doutor Reich. ${ }^{1}$

A primeira memória é não lembrada, o coito de origem, e talvez isso seja um trauma que fará as lembranças ocorrerem somente por volta dos três anos de idade. Do primeiro coito parental até a mais antiga memória, apenas aprendemos a lembrar. Até aí, algo (ou tudo) é indizível, não podemos lembrar dessa alfabetização do aprendizado da lembrança. A falha comum desconhecerá até onde a formação parental nessa época, irá influenciar posturas futuras, ou que bloqueios irá determinar. Algumas experiências de regressão hipnótica pretendem ativar lembranças desde a gestação no útero materno, mas nunca chegam ao encontro do espermatozoide fecundando o ovário - não pode haver lembrança da penetração pai/mãe e nem desse gozo. Ou seja, não pode haver lembrança da nossa própria constituição. Assim, como falar de uma experiência que foi vivida, sentida e nos constitui, se ela antecede a linguagem? como dar testemunho do único se nada dele sabemos, se apenas somos à medida que ocorre em nós?

(...) sendo indizível em nós, sendo a dificuldade em falar sobre a aquisição da linguagem e sobre a morte como destino, ela nunca é vaga. Acontece que a dificuldade apresentada pela função da memória não é a da armazenagem do que foi impresso na matéria do corpo. É a da eleição, da extração, do chamamento e do retorno de um único elemento no âmago do que foi armazenado em bloco [grifo nosso]. $O$ esquecimento não é a amnésia. $O$ esquecimento é uma recusa do retorno do bloco do passado sobre a alma. (...) ele afronta aquilo que se enterra por ser insuportável.(...) O esquecimento é o ato agressivo e primeiro que apaga e que classifica, desenterra e enterra - e reúne para sempre - o esquecido e o retido. ${ }^{2}$

O que leva uma pessoa a eleger essa ou aquela foto numa sequência de similares? ou o que leva um fotógrafo a selecionar determinada imagem numa folha de contato? ou ainda o que leva o editor de um filme a fazer o corte precisamente naquele fotograma? O que aflora é algo que está na imagem, algo a lembrar em detrimento das outras, do que deve ser esquecido. Assim, a escolha é um ato de vida e morte, no qual a eleita só existirá por causa das relegadas, condenadas; começa com uma falha - a linguagem -, e termina com outra - a impossibilidade de ver o próprio fim,

1 Marona, Leonardo. Doutor Krauss. Rio de Janeiro: Oito e meio, 2017. P21.

2 Quignard, Pascal. O nome na ponta da língua. Trad. Ruth Silviano Brandão e Yolanda Vilela. Belo Horizonte: Chão da Feira, 2018. PP60-61. 
esse sim o instante decisivo. Stefan Zweig, escritor austríaco que morava em Petrópolis, RJ, nutria paixão pela pose em seus próprios retratos, como se pudesse controlar a própria imagem. Pelo medo de ser deportado por causa da ascensão do nazismo, preferiu o suicídio junto com a esposa, e até naquele momento, em que se suicidou, arrumou-se na cama como se fosse para uma foto. Os corpos foram encontrados pelos empregados, que avisaram a polícia; o primeiro a entrar foi ou um fotojornalista ou um legista - a foto da cena apresentava o casal na cama: Zweig de gravata, impecável, e ao seu lado, meio desarrumada, a esposa Lotte, como se ela tivesse assistido os minutos finais dele para garantir a pose e só depois se matou. Embora tentasse controlar a cena, não viu a derradeira foto. ${ }^{3}$

=Esta é uma conversa entre imagens que afloram, e que ao se darem a ver escondem segredos; este é apenas um caminho em busca do entendimento da imagem e da memória, em particular da imagem técnica, a fotografia, e quién sabe?!, do trauma.

Para entender viver em um mundo sem imagens, como seria um mundo só fala? Um mundo onde todos fossem cegos, um mundo sonoro. Mas não podemos deixar de pensar na tatilidade, na corporeidade do som, de sons que também são imagens. Como imaginá-los, se formos sempre cegos? E se habitássemos um mundo de silêncios, a linguagem de sinais seria (é) uma fala escultórica. Gesto é fala; o mesmo gesto possui diferentes significados em cada cultura, como o punho cerrado, que tanto pode ser ameaça como resistência (a origem desse gesto entre socialistas e comunistas, deveu-se à necessidade de um prisioneiro, já sem forças ao sair da tortura, informar aos companheiros que nada havia dito). Assim é o papel da mão: produtora da expressão. "Comandando o trabalho manual, o punho é, para os bambaras, o símbolo da habilidade humana." ${ }^{4}$

O movimento do corpo talvez seja o gesto mais antigo. Espernear ao nascer, berrar em busca do ar da primeira respiração fora do ventre, contrair as pálpebras para não abrir os olhos, para não feri-los com a luz. E depois

3 Gissinger, Arno. Seminário Internacional Chamar as chamas. MAR - Museu de Arte do Rio, 2015.

4 Chevalier, Jean. Dicionário de símbolos: (mitos, sonhos, costumes, gestos, formas, figuras, cores, números). Trad. Vera da Costa e Silva... [et al]. Rio de Janeiro: José Olympio, 2003. Extraído de Zahan, Dominique. Sociétés d'iniciation Bambara, Le N'Domo. Paris-Haia: Le Kore, 1960. P747. 
abrir, e piscar. Até piscar é um gesto. Cada piscadela dura cerca de um décimo de segundo. Imaginemos uma sequência de piscadelas, digamos meninos piscando o olho direito como propõe Clifford Geertz, ao falar sobre o objeto da etnografia "como uma hierarquia estratificada de estruturas significantes": a primeira seria um tique nervoso e a segunda seria intencional, como um sinal de cumplicidade; agora, uma terceira, na qual um menino imita o primeiro, para caçoar, mas a imitação não pode ser perfeita senão a intenção de ridicularizar ficará perdida, pois ele não está, de fato, piscando nem tem um tique, está imitando; indo além, diz Geertz, "em dúvida sobre sua capacidade de mímica, o imitador pode praticar em casa diante de um espelho para treinar, e nesse caso ele não está com um tique nervoso, nem piscando ou imitando - ele está ensaiando." Se, para a etnografia é importante perceber essas diferenças de categoria cultural, para a câmera nada disso importa.

(...) o piscador executou duas ações - contrair a pálpebra e piscar - enquanto o que tem um tique nervoso apenas executou uma - contraiu a pálpebra. Contrair as pálpebras de propósito, quando existe um código público no qual agir assim significa um sinal conspiratório, é piscar. É tudo que há a respeito: uma partícula de comportamento, um sinal de cultura e - voilà! - um gesto.

Fig. 2: Andréa Hygino.

Esboço: primeiras capturas, 2017, fotografia, $30 \times 21$ (E); Das vezes que não foi à Lua, 2017, página do fotolivro, $21 \times 30$ (D).
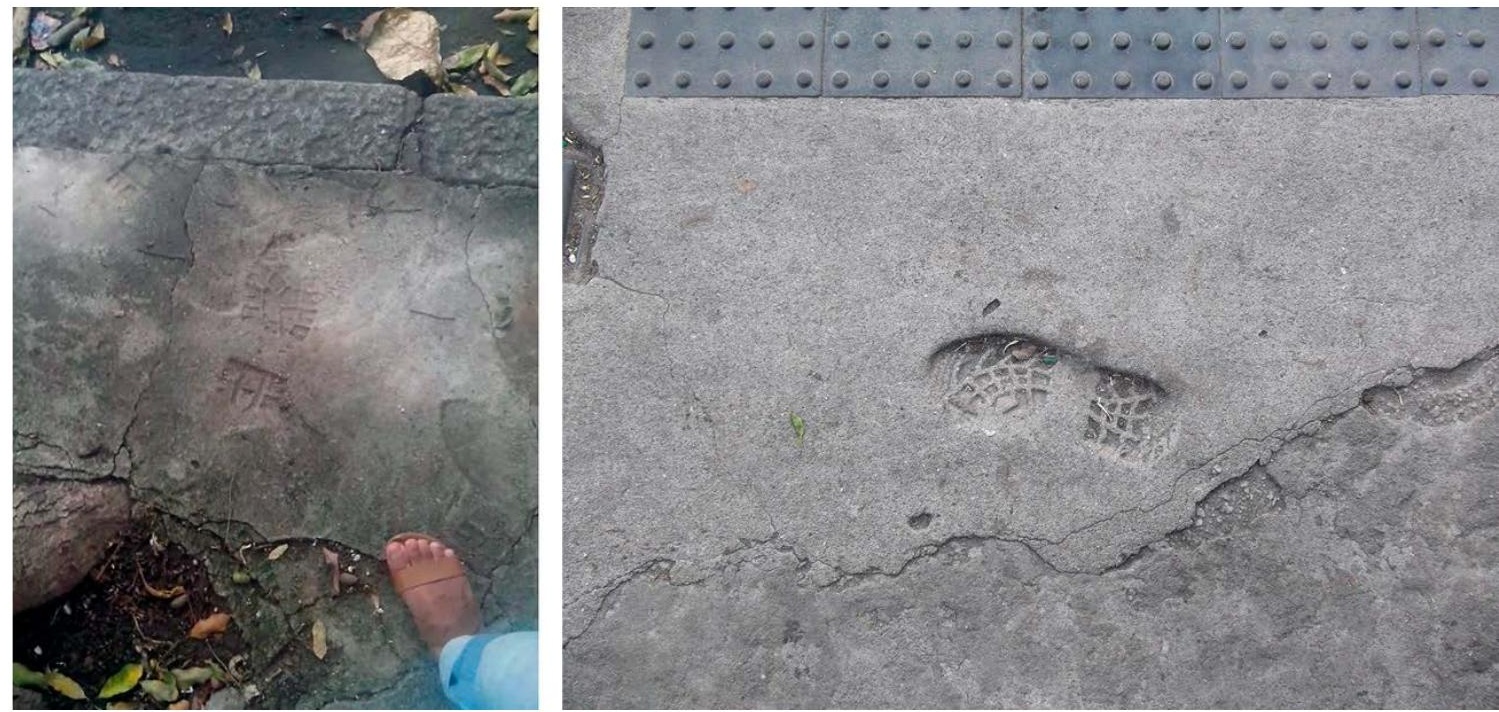

Captura fotográfica de pegadas encontradas no chão da rua. Marcas anônimas, cotidianas, ordinárias. $(\mathrm{AH})$.
5 Geertz, Clifford. A interpretação das culturas. Tradutor não informado. Rio de Janeiro: LTC, 2012. P5. 
Em 14 de abril de 2020, a curadoria da 34a . Bienal de São Paulo enviou um e-mail que começava dizendo "Eu olhei para ele, que mirava o meu rosto". A nota de pé de página explica: "Yo lo miré; él me apuntaba a la cara". Depoimento de um manifestante registrado na reportagem "It's mutilation. The police in Chile is blinding protesters", realizada pelo New York Times. Brent McDonald, Miguel Tovar e Armando De La Cruz, 10 de novembro de 2019.

A notícia trágica refere-se à intencionalidade da polícia chilena de atirar com espingarda de chumbo, mirando nos olhos dos manifestantes com a intenção de cegá-los. No Brasil, foram usadas balas de borracha, com o mesmo efeito de cegar, porém mais dolorosas, se se pode dizer isso. (Este autor percebe e acredita em uma intenção da polícia de atirar em um único olho, como se a cegueira parcial mantivesse aquela memória permanentemente ativa).

Num esforço por ilustrar estas agressões, escrevi uma carta repleta de referências, onde se entrecruzavam notícias tiradas de jornais atuais e as vozes das testemunhas, junto com figuras da literatura de ficção: Lina, protagonista do clássico conto do peruano Clemente Palma "Los ojos de Lina" (1901), que arranca os próprios olhos friamente para que seu amado não tivesse medo de olhá-la de frente; Olympia, a boneca de cera romântica [a autora equivoca-se, não é cera, é madeira] do relato de E. T. A. Hoffman (1816), cujo olhar inerte estremecia os vivos; ou a santa de Siracusa, Lucia, que presenteou os próprios olhos a um amante de seu olhar, para que ele literalmente a deixasse em paz. Mulheres todas que mutilavam os próprios olhos para caminhar livres e à margem do olho masculino, que não se atrevia a olhá-las na cara.

(...) Apenas poucos meses depois [em 2020], o governo chileno decretou novamente o toque de recolher, (...) para tentar frear o contágio da Covid-19. (...).

Do fechamento voluntário dos olhos à mutilação proposital dos mesmos. Dos olhos perdidos aos que sabem muito bem a quem miram. Olhos que, das janelas, controlam quem está na rua. Olhos escondidos em nossos aparelhos celulares que indicam onde estamos para nos manter a salvo. Não importa se abrimos os olhos ou os mantemos fechados, o dia seguinte voltará a chegar. Ainda que agora pareça que o dia e a noite são apenas um mero truque de iluminação. ${ }^{6}$

Outra cena, bem menos violenta, quase uma tragicomédia, ocorreu com este autor. Ao chegar a uma praia, sentei-me e reparei que quase em frente, a uns 15 metros levemente à esquerda, havia um homem de óculos escuros espelhados, talvez com a mesma idade, que olhava fixo em minha 
direção. Incomodado, virei minha cadeira um pouco de lado para evitar a frontalidade dos dois olhares, o dele e o meu. Alguns minutos depois chegou uma família - a mãe, com cerca de 40 anos, sentou-se exatamente à minha frente, cerca de dois metros, pernas ligeiramente abertas de quem busca uma posição confortável, mais à vontade para quem está na praia relaxando. Cumprimentou-me, polida. Para evitar constrangê-la em seu descanso por estar frente a frente com meu olhar, virei um pouco minha cadeira para a direita e eis que a filha adolescente resolveu deitar-se sobre a canga, de bruços, justo no único ângulo que me restava. Não importa o que aconteceu com o resto do dia de praia, essa pequena comédia patafísica, que mais parece um capítulo de Palomar, ilustra a questão que se impõe: quem olhou quem? quem olhou primeiro?

No livro Le toucher, Jean-Luc Nancy, o filósofo Jacques Derrida interroga a primazia do olhador, sinalizando questões do De Anima de Aristóteles "tocadas e retocadas" por Nancy: "Quando nossos olhos se tocam, é dia ou noite?" Quando nos interrogamos sobre qualquer coisa, a coisa nos toca antes de se deixar ver, visita antes da visita, visita sem convite mas que precisará ser recebida, acolhida, hospedada. Ver, então, é uma visita que vem ao dia antes do dia, ou se preferirem, vem à luz antes da luz, como despertar antes do instante de despertar: "Logo, sobre o fenômeno. Ela habita, ela, pré-fenomenológica, a menos que se possa dizer também trans-fenomenal. (...) Aquilo não poderia ter me chegado senão dito tanto quanto tocado: pelo outro." Haveria, então, um olhar antes do olhar? Voltando à questão interposta no início deste parágrafo, se fecho os olhos, ao abri-los vejo claro ou vejo escuro? Quando meu olhar se cruza com outro, quem olhou primeiro? E se dois olhares se cruzam apenas de passagem, por acidente e sem de fato se verem, como que fora de foco, é cegueira ou a memória guardou o instante? Quando cruzo com teu olhar, vejo teu olhar e teus olhos, e eles não são só videntes, mas visíveis; ou inversamente, visíveis e após videntes, e isso nos aproxima, e posso tocá-los, se ousar. ${ }^{8}$

Porque, se nossos olhos veem principalmente o vidente e não o visível, se eles creem ver um olhar mais que os olhos, nessa medida ao menos, nessa medida mesmo, eles nada veem, nada que se veja, nada de visível. Eles soçobram na noite, longe de toda

7 Derrida, Jacques. Le toucher, Jean-Luc Nancy. Trad. Elisa de Magalhães para este ensaio. Paris: Galilée, 2000. P11.

8 Derrida, idem. P13. 
visibilidade. Eles se cegam para ver um olhar, eles evitam ver a visibilidade dos olhos do outro, para se endereçar somente ao seu olhar, à sua vista apenas vidente, à sua visão.

(...)

Para ver o outro nos vendo, a condição seria a de que não víssemos mais a visibilidade, mas somente a vidência de seus olhos??

Fig. 3: Jéssica Guia. A quebra de Narciso, relato e fotoperformance (foto Thiago R. (aetano), 2019, $73 \times 110$.

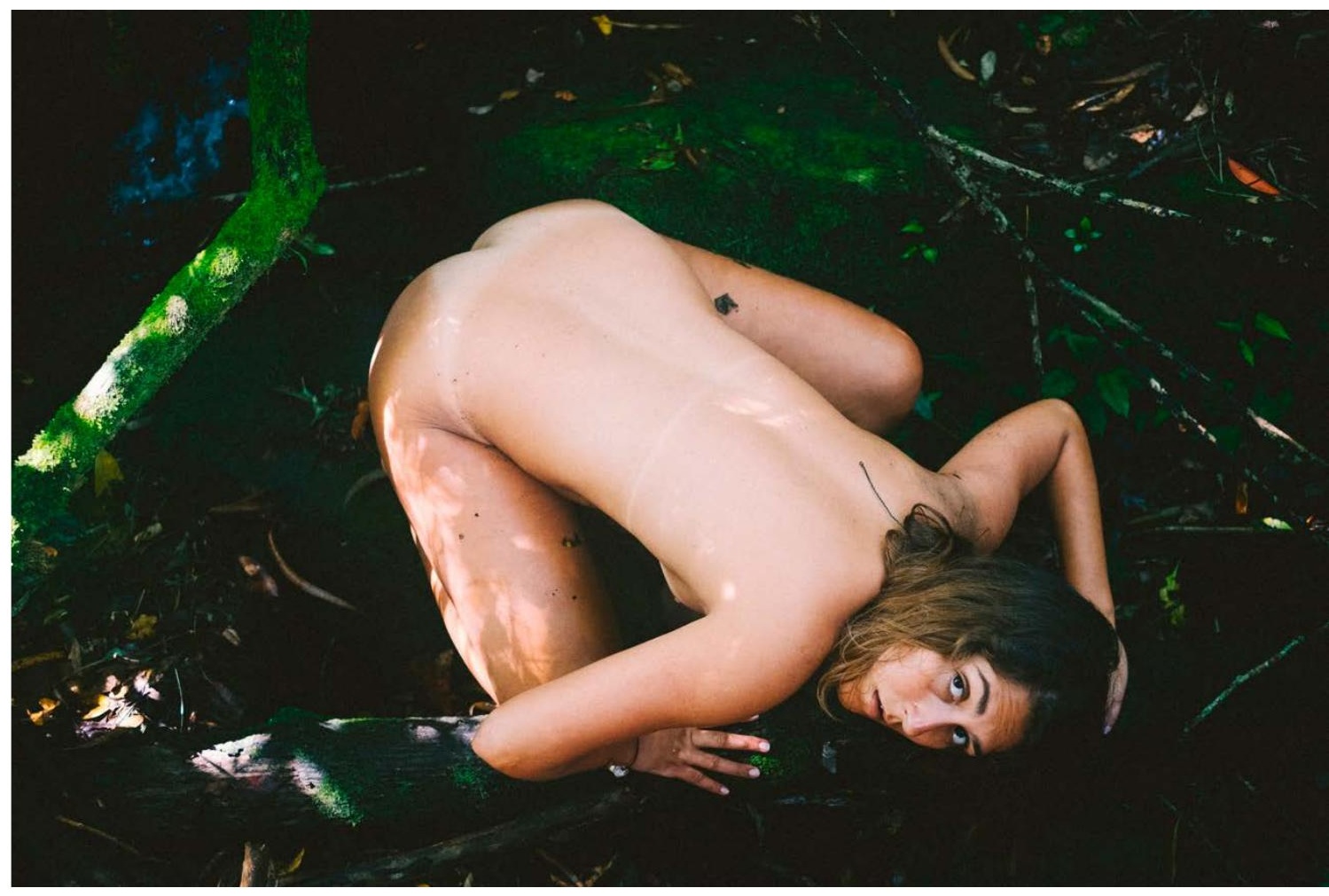

Narciso se apaixona pela própria imagem como uma penitência, seu corpo definha enquanto contempla o próprio reflexo. Em mim, a câmera havia se tornado uma espécie de espelho, no qual eu era ao mesmo tempo objeto de observação e a própria expectadora. Olhar ambíguo, via meu corpo como paisagens, relevos, fragmentos, rastros, silhuetas. Após a tomada de consciência sobre a relação com a câmera, resolvi voltar a atenção para meu corpo. Precisava sair do controle autoimagem, assim pedi a outra pessoa que me fotografasse. Não nos dirigimos, éramos dois corpos, conscientes de nós mesmos e do outro, como se habitando o mesmo espaço e tempo. Os olhares só se cruzaram uma vez, e foi no momento do clique. Esta é a primeira vez que olho para a câmera e não vejo a mim mesma. (JG) 
Algo está - talvez uma pedra no meio do caminho -, esperando nosso olhar. Esperando o encontro com nosso olhar para tornar-se obra. Assim o filósofo Martin Buber descreve a mais bela definição de arte, segundo o também filósofo Rafael Haddock-Lobo. Algo já está, assim como vamos olhando, algo anseia pelo nosso olhar, pois apenas ele pode torná-lo em arte. ${ }^{10}$

Em uma ideia de visão ampliada, se considerarmos obras de arte feitas de som ou de ar, podemos vê-las como sólidos, um tangível invisível ou um visível intangível. Ambientes excessivamente úmidos, quase permitem tocar o ar; o som pode dar-se a ver no tan da quinta sinfonia de Beethoven - tan tan tan tan -, ou ainda na quarta parte da nona com o poema de Schiller, Ode à alegria (ou ao prazer) - coincidência fortuita para este tema: em alemão Ode an die Freude -, lembrando que ele estava surdo quando compôs; sua surdez só foi percebida quando regeu, pois não agradeceu os aplausos que já não ouvia.

Em 1925, para filmar determinada cena do Encouraçado Potemkin, Sergei Eisenstein passou alguns dias à espera do amanhecer ideal para filmagem, por conta da dissipação da bruma. ${ }^{11}$ Outro cineasta russo, Aleksandr Sokurov, em Taurus, ${ }^{12}$ sobre os últimos dias de Lênin, fez um filme com a fotografia tão densa que, para vê-lo em DVD, tem-se que mudar completamente os níveis de contraste normal da imagem no aparelho de reprodução. Há uma experiência pela qual quase todos nós já passamos, que é quando de óculos, ao sairmos de um veículo com ar refrigerado, súbito as lentes se embaçam. Assim, dão-se a ver visíveis e invisíveis, e convivem, ainda que alguns apenas em nossa imaginação, existentes e inexistentes.

O escritor italiano Primo Levi diz que somos responsáveis por dar testemunho de quem perdeu a capacidade de defender-se da violência opressora, que temos a obrigação sem ter o direito, pois nunca podemos falar da dor que não sentimos, da perda que não temos, nem da própria voz de quem não consegue se fazer entender - temos o dever sem ter o direito: as teses sobre o testemunho "articulam uma possibilidade de palavra só por uma impossibilidade e, desta forma, assinalam o ter lugar de uma língua

10 Haddock-Lobo, Rafael, org. Os filósofos e a arte. Rio de janeiro: Rocco, 2010. P11.

11 Didi-Huberman, Georges. A imagem-ambiente. Seminário Internacional Chamar as chamas. EAV Parque Lage, 2015.

12 Sokurov, Aleksandr. Taurus. Russia: Goskino; Lenfilm, 2001. 1h 44'. DVD. 
como evento de uma subjetividade."13 Num outro patamar, o filósofo alemão Ludger Schwarte fala de um testemunho de segunda mão, isto é, não vivemos o que falamos. ${ }^{14}$ Foi assim que nos alfabetizamos, aprendemos fábulas e histórias. Mas que histórias são essas se não pontos de vista? Quando se trata da chamada história do mundo, normalmente contamos a parte do vencedor, ao vencido resta tornar-se vírus para, de dentro da opressão, tentar modificar os costumes do opressor, para sua derrota não ser completa.

Tudo o que vemos e vivemos é memória no instante mesmo em que é visto e, entre imagem e memória há, sempre, mediação. Entendo imagem tanto pelo que se vê como pelo já visto. E até pelo não visto, pois se alguém nos conta ou lemos algo, visualizamo-lo em imagens, inventamos paisagens para o narrado - em nossos diálogos interiores já conversamos em imagens - e, ao fazermos isto, criamos memórias do inexistente. Para resistir, inventamos memória. Assim, somos apenas memória viva. E precisamos dar testemunho da impossibilidade (que é, simultanea e inversamente, impossibilidade do testemunho), temos o dever, talvez não o direito; inundemos, pois, o mundo de imagens, memórias vividas e inventadas e, em algum devir, talvez consigamos mudar para imagens que conversam em imagens.

A partir daqui mudarei de Freude, de Schiller, para Freud, de Sigmund. Relembro que este é um texto sobre imagem, em especial sobre imagens técnicas. Menções e citações dos conceitos de algumas disciplinas, como psicanálise e filosofia, às vezes estão empregados apenas como metáfora, às vezes como atalho; faço para tentar entender melhor aquela que é imediatamente posterior ao movimento e ao som, e que deveriam ter os mais antigos e aprofundados estudos. Devíamos acrescentar o tato, já que descobrimos através da imagem ultrassonográfica que chupamos dedo ainda fetos.

13 Agamben, Giorgio. O que resta de Auschwitz. Trad. Selvino J. Assmann. São Paulo: Boitempo, 2008. P163.

14 Schwarte, Ludger. Seminário Internacional Chamar as chamas. MAR - Museu de Arte do Rio, 2015. 
Talvez tenha sido na obra sem título conhecida como Projeto para uma psicologia científica, de 1895 (publicada postumamente em 1950), que Freud tenha empregado pela primeira vez o termo bahnung.

Ora não é por acaso que Freud, nos momentos decisivos do seu itinerário, recorre a modelos metafóricos que não são tirados da língua falada, das formas verbais, nem mesmo da escrita fonética, mas de uma grafia que nunca está sujeita, exterior ou posterior à palavra. ${ }^{15}$

A fascinação dele por uma formulação maquínica da memória é explícita, embora o que então é posto, só venha a se resolver em 1925, trinta anos depois ao descobrir o Bloco Mágico com sua escrita sem tinta. ${ }^{16}$ Bahnung, do ponto de vista da psicanálise é possível que já não tenha serventia, mas a descrição que ele faz à época, é comparativa com a câmera fotográfica, e mais que isso, o ato de filmar. Na mesma década daquele texto, a equipe de William Dickson, engenheiro da companhia de Thomas Edison construiu a primeira câmera de fazer cinema, o cinematógrafo, e a primeira de projetar cinema, o cinematoscópio, em que o espectador tinha que ver individualmente através de uma lente de aumento o que havia sido filmado. No mesmo 1895, ano do texto do Projeto ..., os irmãos Lumière fizeram a primeira exibição pública de um filme, o plano-sequência L'arrivée d'un train à La Ciotat. A câmera utilizada, chamada de cinematógrafo, tinha a função três em um: filmava, servia de tanque de revelação e projetava a imagem filmada e revelada em seu interior. Quanto à fotografia, a data que se tem da primeira experiência de imagem do mundo que foi fixada em papel, em negativo, ocorreu em 1816, em uma câmera obscura, obtida pelo francês Joseph Nicéphore Nièpce. Já a palavra photographie, foi empregada pela primeira vez em 1834, por outro francês, Hercule Florence, radicado em Campinas, São Paulo. As pesquisas do processo fotográfico, portanto, já estavam em estágio bem avançado em 1895 e a ênfase, aqui, ultrapassa o limite da especulação, coincidência ou curiosidade, pois é quando lemos Freud comparar o cérebro a uma câmera.

15 Derrida, Jacques. Freud e a cena da escritura, in A escritura e a diferença. Trad. Maria Beatriz Marques da Silva. São Paulo: Perspectiva, 2005. P182.

16 Freud, Sigmund. Nota sobre o "bloco mágico", in Obras completas, v. 16. Trad. Paulo César de Souza. São Paulo: Companhia das Letras, 2011. PP267-274. 
Fig. 4: Luis Moquenco. Sem título (Casa), 2020, fotografia, $84 \times 118 \mathrm{~cm}$.

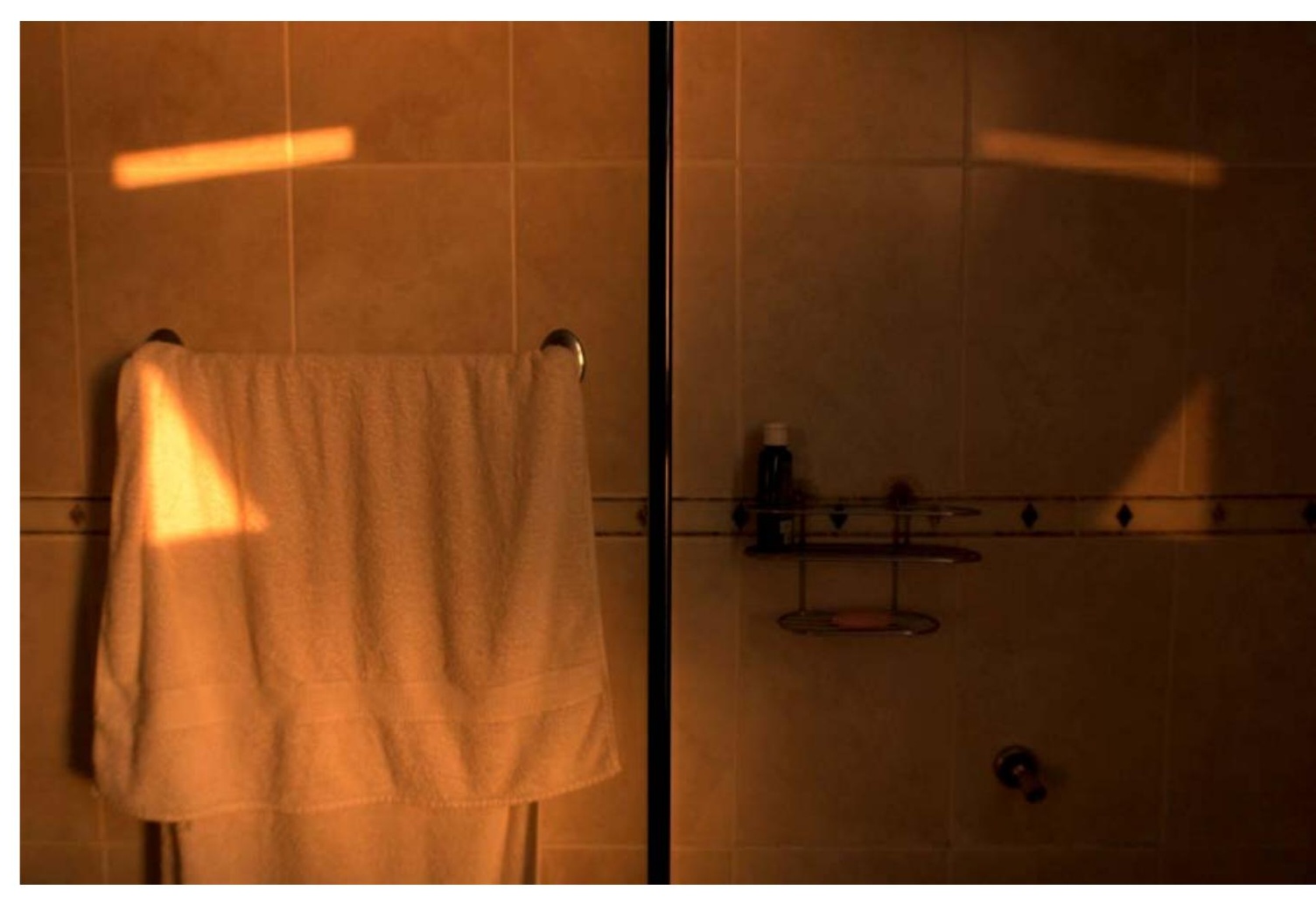

Morar em uma casa que não é minha para a qual não tenho afeto pois faz parte da história do outro é um desafio - entender, mesmo que a princípio não tenha afeto por aquelas coisas, que representam emoções para os outros. Toda história é poder e quanto mais é absorvida, mais se tem poder de construir o próprio futuro. As coisas não são só uma primeira impressão, são cheias de camadas. Não há nada a perder dando chance para as coisas se revelarem. No meu caso, além de dar chance à beleza da memória percebi que certas coisas precisam de luz e tempo para se mostrar. (L. M.)

Passeemos um pouco por câmeras e mentes, mas não sem antes perguntar em que aparelho consiste, de fato, uma câmera, e qual o desejo de apreensão da imagem que remonta à China de Mozi (c. 470 a.C.- c. 391 a.C.), ou Mo Tzu, ou Mo Di; para quê guardar a imagem naquilo que o filósofo chinês chamou aproximadamente de "Armazém do Tesouro" (que equivale ao Banco Central dos países, hoje em dia). E, mais importante, o quê se guarda? A ideia de uma caixa para preservar para sempre o que se está vendo, não teria já daí, a ideia de um aparelho de memória?

Aristóteles (384-322 a.C.) fala da possibilidade de conservar a configuração do sol e da lua, olhados através de um buraco comum. O sábio árabe Alhazen (965-1038) dá a descrição de uma câmera escura, camera obscura, utilizada para observar as eclipses do sol. ${ }^{17}$

17 Keim, Jean-A. Histoire de la photographie. Trad. nossa para este ensaio. Paris: PUF, 
No livro Camera obscura: de l'idéologie, a filósofa Sarah Kofman, define:

Camera obscura: máquina que pintores, como Leonardo da Vinci, utilizavam para imitar a natureza; aparelho de decalque e transparência, revelador do acordo entre o homem e o mundo. Aparelho de perspectiva destinado a eliminar todo perspectivismo. A câmera obscura seria um olho sem ponto de vista, olhar da visão, olhar de Deus sobre o universo.

E, no entanto, no século XIX, a câmara obscura tinha uma conotação negativa. Para Marx, ela é a metáfora da inversão ideológica; para Nietzsche, aquela do perspectivismo generalizado; para Freud, o inconsciente. $O$ quarto escuro vela as ligações com o real, separa a consciência dela mesma e do mundo. A chave do quarto foi jogada fora. A ideia de uma habitação gira narcisicamente em torno dela mesma e procria um mundo fantasmagórico e fetichista. ${ }^{18}$

Tanto a invenção da fotografia quanto a criação da psicanálise por Freud, são produtos do século 19, uma no início e outra no fim. Em pouco mais de 70 anos, nessa pequena diferença de tempo o rápido desenvolvimento das câmeras e dos filmes negativos em preto e branco, propiciou a Freud, para estudar a memória, o uso de várias analogias com a fotografia:

[o] primeiro estádio da fotografia é o negativo; cada imagem fotográfica tem de passar pela prova do "processo negativo" e aqueles negativos que se comportaram bem nesta prova são admitidos ao "processo positivo" que termina com a imagem. ${ }^{19}$

Freud alertará mais tarde que “[a] memória aliás possui sobre o apareIho fotográfico essa maravilhosa superioridade que possuem as forças da natureza de serem elas próprias a renovar os seus meios de ação". ${ }^{20}$ Não interessa aqui a questão psicanalítica da imagem, mas sim esse lugar entre o fenômeno e a linguagem que dá à fotografia uma posição de destaque, como a ideia de que ela, ao ocorrer simultânea ao visto, mimica a construção de uma máquina de memória. Expressões como olho mecânico ou câmera-olho fazem parte dessa estranha relação na qual nos transformamos ou somos transformados em máquina.

1970. P6.

18 Kofman, Sarah. Camera obscura - de l'idéologie. Trad. Elisa de Magalhães para este ensaio. Paris: Galilée, 1973.

19 Derrida, idem. N6. P206.

20 Derrida, idem. N6. PP206-207. 
Algumas ilações são possíveis, especialmente com a apropriação metafórica do conceito de Freud, bahnung. Traduzido como trilhamento ou explorar uma trilha (bahn pode ser traduzido como trilha - daí bahnung pode ser trilhar a trilha) ou grades de contato entre percepção e recordação, aparato psíquico e aparato de memória; a memória implica uma escolha, uma preferência de caminho, "[a] diferença entre as explorações, tal é a verdadeira origem da memória (...)", escreve o filósofo Jacques Derrida em "Freud e a cena da escritura." ${ }^{21}$

O caminho escolhido será, portanto, o caminho explorado, e a cada passo entra em cena nova questão, como a escolha do material que ativará uma economia da imagem: ao longo do século 20, nos grandes centros urbanos a proliferação de pequenas lojas Kodak e de câmeras populares da marca, fazia o elogio da facilidade da imagem e da produção de milhares de ampliações coloridas tamanho postal, a partir de negativos em cor essas pequenas ampliações ( $\mathrm{mal}$ ) preservadas em papel: em que arquivo foram parar essas fotos? de que lembrança elas já não fazem parte? e tudo o que foi visto e que não mereceu ser foto? Sabemos que cada não escolha pode até definir a história, mas não a memória. Tal facilidade da produção da imagem também revela um deslocamento na produção da lembrança, pois o fotógrafo começava a não ser mais contratado para o 'registro' das comemorações importantes, o comemorante transformou-se em seu próprio representante ante a memória (aqui cabe uma pequena observação: na falta de meIhor palavra, deve-se sempre usar a palavra 'fotografia'22 para referir-se à 'fotografia' - o uso da palavra 'registro' é absolutamente inadequado, visto que a fotografia nada registra - aliás, quem registra é cartório). Ainda assim, ou talvez por causa, essa produção massiva de imagens, então assustadora (que nem de perto alcança a proliferação de fotos digitais - mas isso é para outra questão), carrega uma sofisticação no ato de escolha. A imagem se oferece $a$ ele, pessoa com uma câmera, e só acolhendo-a será possível sua (dela e dele) existência, transformá-la em foto, para ser oferecida por ele, o fotógrafo. Mesmo tendo em

21 Derrida, idem. P185.

22 A palavra 'fotografia', que não existia em grego, foi inventada no Brasil, pelo francês Hercule Florence em 1833 para denominar o processo que ele havia descoberto. Para aprofundar a pesquisa sobre o assunto, ver o livro "Hercule Florence: a descoberta isolada da fotografia no Brasil", de Boris Kossoy. 
conta o tempo que uma imagem pode levar para tornar-se pública, ela já está pronta, é memória no ato mesmo de ser clicada.

A palavra trilha (e trilho), é aplicada aqui tanto como substantivo quanto verbo, jogo da palavra que diz respeito à delicadeza da escolha e à formação da linguagem, e que é significativa para a fotografia fixa e o cinema, pois em ambos corre o filme: relembremos, a própria ideia de cinema praticamente surge sobre um - na tomada única de L'arrivée d'un train en gare de La Ciotat, de 1895, a imagem é de um trem sobre trilhos que avança em direção aos espectadores.

Curiosamente, a imagem que é tomada pela câmera cinematográfica é produzida de maneira inversa à da câmera fotográfica. O visor permite que se veja em tempo real (embora com uma pequena diferença lateral) o que está sendo filmado; além, disso, a passagem de luz que impregna o filme precisa ser controlada - quase o mesmo princípio da fotografia parada -, o que processado através de uma máscara que veda e abre a passagem da imagem em vários quadros por segundo, ${ }^{23} \mathrm{como}$ se fossem piscadelas. Como também não interessa a história do apareIho fotográfico, dou apenas um sobrevoo nos dois principais modelos de câmeras de fotografia analógica que viraram febre ao longo do século 20. Com o desenvolvimento da imagem técnica, a necessidade de mobilidade para fazer fotografia, inventou as câmeras $35 \mathrm{~mm}$, nas quais o filme corre sobre trilhos. Dessas, as primeiras tinham visor externo e logo ganharam a correção da paralaxe, tentativa de ver ao mesmo tempo que a máquina o que era fotografado; posteriormente vieram as câmeras reflex, nas quais a imagem passou a ser vista através das lentes, num jogo de espelho e prisma que sobe e desce, e sugere semelhança com o brinquedo bloco mágico que, ao levantar a folha, apaga

o traço; ao devolver a folha, apaga a memória - a foto resta como memória, ela torna o que foi em é, ainda que não tenha sido assim, e já não importa pois restará a foto como prova que não prova nada, apenas a invenção de um outro real que teria sido possível. Das duas câmeras $35 \mathrm{~mm}$ : uma com visor lateral - dois olhos que não se encontram, o cego da câmera e o deslocado do fotógrafo; e outra, reflex, que tenta simultaneizar o ver/gravar, através do espelho que levanta na hora do 
Fig. 4: Luiza Coimbra. Museu Nacional, 2018. Fotografia. $40 \times 30 \mathrm{~cm}$.

Figs. 5 e 6: Luiza Coimbra. Anjo, 2012. Fotografia. $30 \times 20 \mathrm{~cm}$. clique impedindo o olhar, mas torna cego o instante da imagem sendo impregnada: são esses dois olhos cegos que inventam memória. Há, sempre, uma pequena diferença de tempo do ver ao fotografar, e é esse enceguecimento no ato que impede a visão real do evento, que sempre chega como susto pois não se sabe de fato o que foi fotografado - ou seja, o ocorrido não foi simultâneo na câmera e na memória, não mais existe o instante pois houve um delay; nesse instante de cegueira, a foto é o que fica, o que resta, o que deixa a marca, o traço; é o que envolve o ato imediatamente, antes e depois; a foto é a memória que irá construir outra história, inventar outro mundo além daquele do qual o fragmento foi retirado, parte de algo ausente, princípio com o qual nasce, sempre parte e todo; e assim, isolado ou em novo conjunto constituir-se obra que se faz, se presenta e discute sua própria existência, inclusive através do que falta.
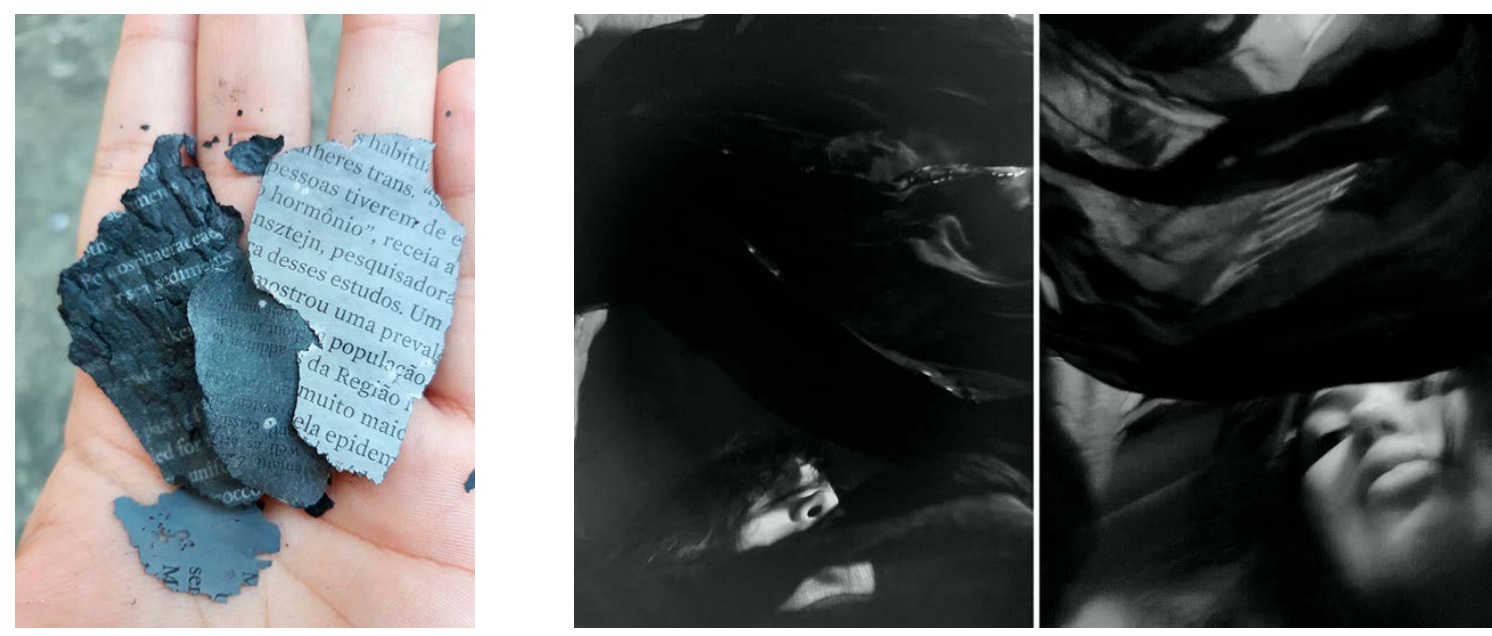

(FIG 4). Da série de autorretratos a partir das Elegias de Duíno, de Rainer Maria Rilke. (FIGS. 5 E 6) Fotografias de cinzas de documentos do incêndio no Museu Nacional que voaram até minha casa. (LC).

Todavia, o que importa aqui é pensar o fenômeno, a imagem e a imagem fotográfica, e o ato de ver. Na tentativa de trazer à luz um pouco mais do conflito imagem/palavra, o filósofo Paul Ricoeur, em sua fala do pensamento de Freud sobre arte, diz que "o universo de discurso apropriado à linguagem analítica não é a linguagem, mas a imagem". Em duas palestras, em 1974 e 1978, publicadas em seu livro Escritos e conferências 1- em torno da psicanálise, comenta diversos textos de Freud em busca de um sistema que se utiliza da convertibilidade entre linguagem e signo, e que chamou de "semiótica da imagem": 
A psicanálise só conhece o desejo do que pode ser dito. Compreendamos bem: não se trata aqui de modo algum da amputação da experiência humana reduzida ao discurso, mas, ao contrário, de uma extensão da esfera semiótica até os confins obscuros do desejo mudo de antes da linguagem. ${ }^{24}$

Ricoeur diz que em psicanálise tudo é palavra e linguagem, ${ }^{25}$ embora nem tudo que vira linguagem seja, de fato, linguagem, ${ }^{26}$ o que torna o trabalho de interpretação mais difícil. Ele compara o que Freud chama de "material psíquico do qual o sonho é feito", ao das artes plásticas, a imagem que exprime e indica ideias plasticamente. ${ }^{27}$ Assim crê que a linguagem deveria funcionar num nível pictorial para ser vizinha da imagem visual, e vice-versa. ${ }^{28} \mathrm{O}$ que a obra de arte possibilita "é que jamais nos relacionamos com signos, mas com signos que já são signos de signos de signos." ${ }^{29}$ A arte, e mais até a imagem técnica não se limita a exibir o objeto do desejo, quase o torna tangível, quase o dispõe ao alcance, num provocante jogo de reflexão. O fazer da imagem é decisão individual, tomada no acontecimento.

Se aprofundássemos essa questão, diria que fotógrafos e fotógrafas têm um fazer extremamente solitário, e não raro dizem ter por companheira apenas a câmera - a analogia da mulher-máquina ou da máquina-mulher, ou a Olympia citada mais acima do conto $O$ homem de areia de E. T. A. Hoffman, que também fala de uma enucleação, é relacionada em outro texto de Freud com castração; do enquadrar uma imagem diz-se fazer um corte, um corte no dito real, um ato de enceguecimento. Pode-se desenvolver essas colocações a partir do estudo de Georges Bataille, A oreIha cortada de Van Gogh, que também leva a pensar o colocar-se em imagem, o autorretrato, mesmo que transversalmente, estudado por Freud, por Walter Benjamin em Passagens e por Jacques Lacan no Seminário 11. Mas isso é para outra história. Resta apenas perguntar: para onde vão as imagens? E, com elas, vão as imagens nas imagens? No campo cego da memória, no qual todas se refugiam, algo sempre nos escapa?

24 Ricoeur, Paul. Escritos e conferências 1 - em torno da psicanálise. Trad. Edson Bini. São Paulo: Loyola, 2010. P83.

25 Ricoeur, idem. P93.

26 Ricoeur, idem. P96.

27 Ricoeur, idem. P97.

28 Ricoeur, idem. P99.

29 Ricoeur, idem. P184. 
Há uma indicação de trilha neste trecho de um poema de Ernst Jünger:

Aí, onde as imagens desaparecem, elas devem ser substituídas por imagens, caso contrário há ameaça de perda. ${ }^{30}$

Piscar, piscar, piscar.

Fig. 7: Wilton Montenegro. La luna luna. 1969-2018, fotografia. $60 \times 90 \mathrm{~cm}$.

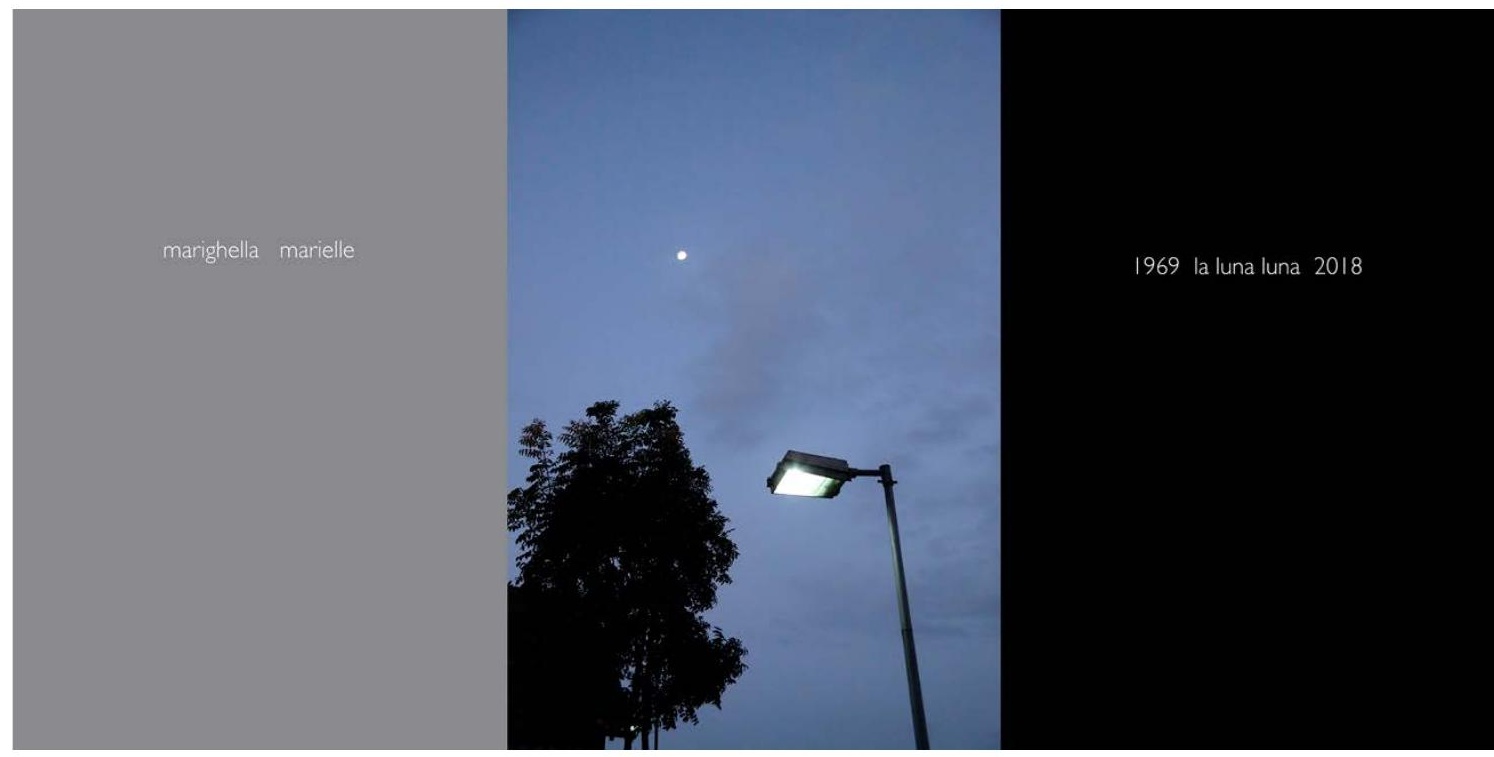

Esta imagem faz parte da série Plataforma (em francês La jetée), que é constituída a partir de questões da fotografia no cinema. Segundo Chris Marker, metade do que vemos na projeção de um filme não tem foto, é matéria preta. Ao editar um filme, para evitar que uma imagem nova arraste memória da imagem que acabou de ser vista, são inseridos 5 ou 6 cliques pretos, caso contrário o olho carrega o rastro da imagem anterior na imagem nova como na piscadela, ou seja, é vista mesmo que não esteja sendo enxergada, projetada. Nessa série, usando o preto como massa ou moldura, foram feitas diversas imagens em outras variações, sempre no sentido de evitar os rastros de outras imagens; nesta, como uma metaimagem, a negação da negação: tanto Carlos Marighella quanto Marielle Franco morreram assassinados em emboscada do sistema policial militar. (WM).

Recebido: 20 de abril de 2020; Aceito: 26 de outubro de 2020

Este é um artigo publicado em acesso aberto sob uma licença Creative Commons

(cc) BY

30 Junger, Ernst. Die Schere, in Damisch, Hubert, O desaparecimento da imagem. Trad, Anamaria Skinner. Rio de Janeiro: Revista Arte e Ensaios 31, 2016. P93. 